\title{
Vietnamese Students Employability Skills
}

\author{
Nguyen Minh Tuan \\ School of Business, International University \\ Vietnam National University of Ho Chi Minh City, Vietnam \\ Tel: 84-8-(0)913-920-620 E-mail: nmtuan@hcmiu.edu.vn
}

Received: May 23, 2011 Accepted: June 8, $2011 \quad$ Published: November 1, 2011

doi:10.5539/ies.v4n4p175 URL: http://dx.doi.org/10.5539/ies.v4n4p175

\begin{abstract}
This paper attempts to investigate if the International University (IU) students' core competencies can meet the requirements set by employers, what are the differences in core competencies in final year students (or undergraduates), and how they view themselves compared with ex-students after one or two years in working environment, how differences in levels of competencies which are expected to outperform the job expectations and competencies possessed by ex-students, and any differences in levels of competencies self-rated by undergraduates due to gender. Questionnaires, mean score comparison, independent-samples T-tests, paired-samples T-tests are used to analyze data collected from 120 employers/managers in various companies/organizations in Ho Chi Minh City and Binh Duong province, 105 ex-students, and 102 final year business students. The core competencies are drawn from the behavioral competency dictionary of Organizational Readiness Office, Canada (2007). The research results can provide good suggestions to IU in specific and other foreign invested universities in Vietnam to produce competent students for the ever-changing labor market.
\end{abstract}

Keywords: Employability skill, Undergraduate, Competency, Dictionary

\section{Introduction}

Vietnam is an emerging market experiencing fast changes in the last two decades. Having a sufficient skilled labor force is one of the key drivers behind this success. However, in order to sustain the growing economy, Vietnam must face the challenge of providing more skilled labor, which can satisfy various demands from different employers. Being aware of shortage of the high-skilled labor needed to supply the new demands and the stiff global competition, especially after joining WTO in 2007, the Vietnamese government established the International University in 2003 - a member of Vietnam National University of Ho Chi Minh City. This is the first public university in Vietnam to use English as the only means of teaching all subjects. The university recruited its first students in 2004 and the majority of them graduated in 2008.

The evaluation of "IU products" in terms of employability skills is very crucial for its long-term success. As a pioneer in utilizing English as a means of teaching, a growing concern is that its graduates cannot match the business requirements. According to Khir (2006), graduates now are in short of both technical know how and generic skills. Universities are under massive pressure to provide students with more than just discipline-based skills. Universities need to emphasize their efforts to supply 'soft skills' needed in various areas of employment. It is a must for universities to work closely with industry to satisfy the needs of employers. According to Bailey, (Mitchell, 2006) "to succeed in this ever changing, increasingly competitive business environment, organizations must demand employees with competencies which will lead to a high return on the employee investment". Vietnam which is integrating into global economy is expected to face the same challenging task.

Finally, according to the commitment made by Vietnam government to join WTO, Vietnam have opened the education market to foreign universities since 2010. Vietnam should expect that there are more foreign universities to come in a near future. By its own specific model of teaching, IU should consider them as direct competitors. Thus, it is an urgent need for IU to understand the quality of its products in the viewpoint of social acceptance.

\section{Literature Review}

Before, the higher education situation in Vietnam was for the elite. Graduates from universities with good transcripts would automatically become officials under the planned economy systems, and this influenced the employment expectation of graduates and their parents. With the evolution of our economy, this is no longer true. Higher education in Vietnam has been moved into a more common education. The number of higher education institutions 
in Vietnam has been increased to 376 with 1.7 million university students in comparison with the population of 85 million, according to Wikimedia (2011). With the fast expanding of the higher education system, the difficulty for Vietnamese graduates now is that they cannot find good jobs as they expected. In the last survey conducted by Ministry of Education and Training (MOET) of Vietnam in 2007, there are only 25 among 89 universities (i.e. $28.09 \%$ ) with more than 60 percent of undergraduates finding appropriate jobs in their majors within a year from graduation.

Recent shifts in education and labour market policy have resulted in universities being placed under increasing pressure to produce employable graduates (Ruth Bridgstock, 2009). While academic credentials are still seen as a significant dimension of their employability, students increasingly see the need to add value to them in order to gain an advantage in the labour market (Michael Tomlinson, 2008). Graduate recruiters require a variety of other skills, personal and intellectual attributes; rather than specialized subject knowledge (Wye, 2009). Changes in organizational and employment structures have been widely recognized as the causes that demand expanding types of skills required by employers. (Brown, Green Lauder \& Sakamoto, 2001; Kamarainen, Attwell \& Brown, 2002; Kamarainen \& Streumer, 1998). Landkard (1997) also mentioned that the current working environment has changed from the previous one. Global competition, cultural diversity, advancements in technology, and new management processes have demanded more skills from employees.

The concept of employability is largely referred to as graduates' possession of certain skill levels and attitudes, as well as their ability to use them to search for jobs and retain positions (Nabi, 2003). Employability skills are not job specific, but are skills that cut horizontally across all industries and vertically across all jobs from entry level to chief executive officer (Sherer and Eadie 1987, p16). De Leon and Borchers (1998) studied skills required by Texas graduates working in production industry. The study found that group interaction, employability, and self-development are the three most important skills required by employers. Lees (2002) reviewed employability skills literature, then compiled the following key skills and qualities which are required by employers: (1) Personal Qualities which include malleable self-theory, self-awareness, self-confidence, independence, emotional intelligence, adaptability, stress tolerance, initiative, willing ness to learn, and reflectiveness. (2) Core Skills which include reading effectiveness, numeracy, information retrieval, language skills, self-management, critical analysis, creativity, listening, written communication, oral presentations, explaining, and global awareness. (3) Process Skills which include computer literacy, commercial awareness, political sensitivity, ability to work cross-culturally, ethical sensitivity, prioritizing, planning applying subject understanding, acting morally, coping with ambiguity and complexity, problem solving, influencing, arguing for and/or justifying a point of view or a course of action, resolving conflict, decision making, negotiating, and team work.

Harvey et al. (1997) showed that employers in UK tended to value generic skills more highly than disciplinary-based understanding and skills. Purcell and Pitcher (1996) found that over $40 \%$ of 'graduate jobs' which are advertised in the UK has been indifferent to applicants' subject of study. For many employers, the major studied is not as important as the ability to handle complex information and good communication skills (Knight \& Yorke, 2002). "Employability skills are defined as skills required not only to gain employment, but also to progress within an enterprise so as to achieve one's potential and contribute successfully to enterprise strategic directions." (DEST 2002a). The report published by the US Department of Labor (2000) states that graduates must master employability skills in order to find meaningful work. Employability skills are given utmost importance in campus interview and certainly help them execute the assigned works efficiently in any institution after the selection process (V. Saravanan, 2009)

\section{Research Objectives}

In this article, the business major graduates (or ex-students) who just completed their academic programs between one and two years ago, and are working in various enterprises are asked to evaluate the skills that they possess at present, and the skills required so as to be able to successfully perform tasks and advance in their profession. The employers/managers from various enterprises/organizations are asked to give their expectations of the skills possessed by applicants who just graduated from universities. The final group surveyed was the final year business major students from IU. They were asked to identify skill levels possessed and how much assistance IU has helped them improve during the studying period of four years.

The main objectives of this research are as follows:

- To identify whether IU students are able to meet employers' requirements to get meaningful jobs.

- To identify the important employability skills as perceived by employers and by IU students. 
- To identify the improvement levels of IU students in employability skills during their four-year study period.

- To identify the changes of IU students about employability skills before and after graduation.

- To examine whether there is any gender difference in self-rating levels of competencies possessed by undergraduates.

\section{Research Questions}

- What are the differences between core competencies possessed by IU students and those required by employers?

- Which core competencies that fall short of employers' expectation?

- How much improvement have IU students displayed in these core competencies?

- After being active in working environments for about one year, are there any significant changes in their core competencies?

- Is there a gender difference in self-rating levels of core competencies possessed by undergraduates?

\section{Research Methodology}

As previously stated, a survey has been conducted on three different samples, namely employers, ex-students, and final year business students. 120 sets of questionnaires were distributed to employers/managers in various companies in Ho Chi Minh city and Binh Duong province. 105 sets of questionnaires were given to ex-students, and 102 sets of questionnaires were handed over to final year business students. The questionnaires for employers were distributed personally by the researcher. The questionnaires for ex-students and final year students were distributed by hired students of IU. These questionnaires were collected immediately after completion by respondents.

The three types of questionnaires were designed based on the 'Behavioural Competency Dictionary' of Organizational Readiness Office of Canada in February, 2007. There are 24 competencies in this dictionary. These competencies were translated into Vietnamese to facilitate reading comprehension and avoid misunderstanding due to the fact that English is not very commonly used in Vietnam. The Vietnamese version of this dictionary has been scrutinized carefully in the following ways:

- This Vietnamese version was delivered to 4 International students, 4 ex-students, and 3 employers/managers. They checked for the appropriateness of 24 competencies that are required from students or ex-students, and the wording in the Vietnamese-versioned dictionary.

- A meeting of the 11 people mentioned above was organized and all feedback was collected. In the meeting, all the feedback was examined and discussed carefully. Final decisions were made based on consensus after that. The competencies 'Developing Others', 'Impact and Influence', and 'Visioning and Strategic Direction' are eliminated. The final Vietnamese-versioned dictionary has been agreed.

While rating level of skills/competencies, many Vietnamese meet with difficulty selecting appropriate numbers. With the help of the explanations attached for each competency, the deviation due to misunderstanding each competence has been reduced.

The questionnaire for employers consists of four sections. Section 1 captures the demographic information of the respondents. Section 2 asked them to rate their level of competency for each skill listed with a five-point Likert Scale measured from 1, being "very low level" to 5, being "very high level". Section 3 asks them to rank the top ten skills that they think as important to employability. Section 4 with open-ended questions provides opportunity for respondents to suggest any skills that are not listed in the questionnaire but appear to be important to staff under their management. The respondents were also asked to make suggestion on any activity that universities need to implement to support students and ex-students.

The two questionnaires for ex-students and students also consists of four sections. Sections 1,3 and 4 in the two questionnaires are the same as in sections 1,3 , and 4 of the questionnaire for employers. The difference comes from the section 2:

- The ex-students were asked to rate their level of competency being possessed, and the level of competency, which they need to outperform their jobs, with a five-point Likert Scale measured from 1, being "very low level" to 5 , being "very high level". 
- The undergraduates were asked to rate their level of competency being possessed with the five-point Likert Scale as the above. The undergraduates were also asked to rate how helpful the IU program has done to their improvement on these competencies since their freshman year.

The number of employers/managers, ex-students, and undergraduates who responded in the survey was 80,44 , and 70 respectively. The corresponding response rates for the three above groups are $66.7 \%, 41.9 \%$, and $68.6 \%$.

The competencies that were surveyed and labeled in this study are as follows:

- Adaptiv:

- Crithi:

- Leader:

- Client:

- Communi:

- Confli:

- Learn:

- Create:

- Deci:

- Initia:

- Network:

- Environ:

- Partner:

- Plan:

- Result:

- Risk:

- Resour:

- Stress:

- TeamWor:

- TeamLea:

- Ethic:

- English:
Adaptability

Critical Thinking

Change Leadership

Client Focus

Communication

Conflict Management

Continuous Learning

Creativity Thinking

Decision Making

Initiative

Networking/Relationship Building

Organizational and Environmental Awareness

Partnering

Planning and Organizing

Result Orientation

Risk Management

Use of Resource

Stress Management

Teamwork

Team Leadership

Value and Ethics

English skills

Suffices: $\mathrm{N}, \mathrm{R}$, and $\mathrm{H}$ with the following meanings:

- $\quad \mathrm{N}$ : Now e.g. AdaptivN is understood as the Adaptability being possessed.

- R: Required e.g. AdaptivR is understood as Adaptability required for the job.

- H: Help e.g. AdaptivH is understood as how helpful the IU program has been done for your improvement on Adaptability competence.

\section{Findings}

Table 1 displays

- different competencies, with means and standards of deviation of levels required by employers.

- different competencies, and means and standards of deviation of levels which are being possessed by ex-students who just graduated between one and two years before.

- different competencies, and means and standards of deviation of levels expected by ex-students to be able to perform present jobs well.

- different competencies, and means and standards of deviation of levels being possessed by students.

Table 2 shows that the Independent-Samples $T$ test is used to check any statistically significant differences between level of competencies possessed by final year students and those required by employers/managers ( 0.05 alpha level). The differences in the following competencies are detected: Communication, Continuous Learning, Organizational and Environmental Awareness, Use of Resources; in which 
- Communication; Use of Resources: levels of competencies rated by undergraduates are higher than those required employers/managers. The interpretation for this can be the IU undergraduates nowadays tend to overestimate in these competencies. IU is the first university in Vietnam that has applied a new curriculum tailored from US universities' using English as the means of teaching. Fifty percent of teachers in IU come from various countries around the world such as US, Canada, Australia, UK, Singapore etc can make major contribution to this.

- Continuous Learning; Organizational and Environmental Awareness: levels of competencies rated by undergraduates are lower than those required by employers/managers.

- For Continuous Learning competence: IU undergraduates get 2.94 but employers require 3.34. Based on the behavioural competency dictionary, IU undergraduates are only able to seek learning opportunities beyond current requirements. To improve their employability, IU undergraduates must know how to align personal development with objectives of organization. They need to design personal learning objectives based on evolving needs of the portfolio or business unit. They should use organizational change as an opportunity to develop new skills and knowledge.

- For Organizational and Environmental Awareness: IU undergraduates get 2.81 but employers require 3.3. Based on the behavioral dictionary of competency, IU undergraduates are close to effectively operating in external environments. They need to understand organizational politics, issues and external influences to improve their employability skills.

Table 3 shows that the Independent-Samples $T$ test is used to check any statistically significant differences between the levels of competencies possessed by ex-students and undergraduates. There are differences in the following competencies: Change Leadership, Conflict Management, Networking/Relationship Building, English skills; in which

- English: This competency has been much improved. The mean of English level has changed from 1.86 (with 2 as equivalent to TOEFL 550 or IELTS 6.0) to 2.52 (with 3 as equivalent to TOEFL 600 or IELTS 7.0). The most likely explanation is that Vietnam economy has integrated into the world economy with many foreign companies coming to Vietnam, especially after Vietnam joined WTO in 2007. With good English, many IU undergraduates works for foreign invested companies or have opportunities to use English doing business at their current positions. They recognize the importance of English fluency, and put much effort to improve.

- Change Leadership, Conflict Management, and Networking/Relationship Building: ex-students rated themselves lower than undergraduates! In other words, after graduation and working in organizations, these levels of competencies would be decreased! The most likely answer for the decrease is that the working environment appears to be more complicated than study environment. In study environment, students need to manage, lead, and enable the process of change going from freshmen to seniors; prevent, manage, and resolve conflicts between students with conflicts mainly in positions/perception but not benefits; build and actively maintain relationships and/or networks of contacts to further their study goals. However, in working environment, ex-students recognize

- the change is for organizational objectives but not for their own.

- the conflicts are in a wider scope with various motive such as money, rewards, promotion, benefits in kinds.

○ the networking/relationship building includes not only between peers but various stakeholders. The purpose of networking/relationship building is not only social needs as classified in Maslow's theory but to further the organization's goals.

Table 4 shows that the Independent-Samples $T$ test is used to check any statistically significant differences between the levels of competencies possessed by ex-students and those required by employers/managers.

There are differences in the following competencies: Change Leadership, Communication, Networking/Relationship Building, Organizational and Environmental Awareness, and English; in which:

- Communication, and English: Ex-students possessed higher levels by comparison with employers' requirements.

- In Communication, the mean is 3.14 for ex-students but only 2.55 for employers. 3.14 for ex-students but only 2.55 for employers. Based on the behavioural competency dictionary, 
employers require newly recruits to be able to foster two-way communication or adapt communication to others.

○ ex-students have English levels much higher than employers' requirements. With the mean of 2.52 (equivalent to TOEFL from 550 to 600, or IELTS from 6.0 to 7.0), ex-students are good English users with few misunderstanding in unfamiliar situations.

- Change Leadership, Networking/Relationship Building, Organizational and Environmental Awareness: ex-students need improvement. The working environment is very much different from study environment. Undergraduates who are adepts in study environment need to make significant changes to adapt well into new working environment.

- For Change Leadership, the mean of ex-students is 2.39 but that of employers is 2.99. Based on the dictionary of competency, ex-students need to focus on managing the process for change. Ex-students must be able to identify important effective practices that should continue after changes are implemented.

○ For Networking/Relationship Building, the mean of ex-students is 2.52 but that of employers is 3.05. Based on the behavioral competency dictionary, ex-students need to focus on seeking new networking opportunities for self and others. They should seek opportunities to partner and transfer knowledge (e.. by actively participating in trade shows, conferences, meetings committees, multistakeholder groups and seminars). They should cultivate personal networks in different pars of the organization and effectively uses contacts to achieve results. Furthermore, they need to initiate and develop diverse relationships

- For Organizational and Environmental Awareness, the mean of ex-students is 2.55 but that of employers is 3.3 which is of the highest means of competencies. It shows that this skill is rated as of especial importance. Based on the behavioural competency dictionary, ex-students should learn how to effectively operate in external environment. Furthermore, they should understand organizational politics issues, and external influences.

Table 5 shows the differences between levels of competencies that are expected to outperform the job and competencies possessed by ex-students. Using paired-samples T-test, the results show that there are differences in means of all competencies at 0.05 alpha level. This can be interpreted as ex-students consider all competencies are important and they need for improvement in all these competencies, even they can meet the employers' requirements in their current jobs. They do not only want to perform the existing jobs better but also to go further in professional advancement and personal development. The biggest gap is in networking/relationship building. The mean being possessed is 2.52 but that required is 4.00 . Based on the behavioural competency dictionary, ex-students want to strategically expand their network with parties that can enable the achievement of the organizational strategies. They want to be able to bring informal teams of experts together to address issues/needs, share information and resolve differences, as required. They should learn how to use knowledge of the formal or informal structure and the culture to further strategic objectives. The smallest gap is in English. The mean being possessed is 2.52 but that required is 2.93. The interpretation can be that IU students possess quite high level of English at graduation. If they work for foreign invested companies, or often do business internationally, they know how importance of English skills and quickly focus on improvement. After one or two years, they can be confident using English in various business activities. However, with the requirement of 2.93, the English level required is close to TOEFL 600 or IELTS 7.0, and it is difficult to achieve this in Vietnam, a non-English speaking environment. In other words, it requires much effort and resource to improve their English at this level. The ex-students can have calculation here to see whether their effort in improving English skills can be offset by the rewards that can be brought back.

Table 6 shows the gender differences in levels of competencies self-rated by undergraduates. Using independent-samples T-tests show that there is no statistically significant difference, at alpha level of 0.05 , between male and female students, except in the following competencies: Change Leadership, Networking/Relationship Building, Results Orientation, and Team Leadership. Male students rate themselves higher by comparison with female in these competencies. However, all difference levels between 0 and 1 denote low difference levels between male and female students. The Networking/Relationship Building records the highest level of mismatch of 0.70, in which male students record 3.38 and female students record 2.67. Based on behavioural competency dictionary, female students seek new networking opportunities for self and others, but male students lean toward to strategically expand their networks. 
Table 7 shows the assistance IU has brought to undergraduates to improve their competencies during study period in IU. The result postulated a rather good performance from IU in helping them in develop the competencies (i.e. the mean of 3.02 for all competencies). Among them, undergraduates highly appreciate the assistance from IU in the following competencies: Teamwork, Team Leadership, Communication, Continuous Learning, Initiatives, Adaptability, Change Leadership, Values and Ethics, Conflict Management, and Decision Making. The Teamwork records the highest level of assistance (3.53). This can be explained with the curriculum of IU. During study period at IU, undergraduates have received many group assignments in various subjects. Teamwork spirit can also be developed though sports, local group drama, volunteer forces. Undergraduates think that they receive the least assistance in improving two competencies: Result Oriented and English with both assistance levels of 2.76. However, 2.76 is still not too far from the average of the scale. Furthermore, with the standard deviation of 0.21 , IU has provided undergraduates useful assistance in these competencies.

\section{Conclusions and Policy Implications}

Employability skills are very important to undergraduates, ex-students, and employers. By taking into account employers' requirements on various competencies and their assessment on ex-students; ex-students' rating of various competencies being possessed, and their expectation levels; undergraduates' rating on various competencies being possessed and the assistance levels brought to them through the study period, IU can have insights of how society has evaluated their products, then make appropriate modifications and adjustments in their curriculum for its further improvement and advancement.

Research findings show that IU undergraduates rate themselves in various competencies as equal to those required by employers, especially in Communication and Use of Resources, in which IU undergraduates rate themselves higher than the required by employers. This attitude can bring confidence in job interviews, and as a consequence good jobs with appropriate benefits can be achieved. However, this can bring many disadvantages if these undergraduates cannot actually perform at the levels that are generated in the interviews. For Continuous Learning and Organizational \& Environmental Awareness, IU undergraduates rate themselves lower than the required by employers. IU undergraduates need to be aware of how to align their personal development and objectives of organization. They should know how to design personal learning objectives based on evolving needs of the portfolio or business unit. They should learn how to use organizational change as an opportunity to develop new skills and knowledge. They need to understand organizational politics, issues and external influences. They should learn how to anticipate issues, challenges and outcomes and effectively operate to best position the organization. They need to know how to support the changing culture and methods of operating, if necessary for the success of the organization, and ensure due diligence by keeping informed of business and operational plans and practices.

Besides that, in general, levels of competencies possessed by ex-students and undergraduates are not much different except in Change Leadership, Conflict Management, Networking/Relationship Building, and English skills, in which undergraduates rate themselves higher in Change Leadership, Conflict Management, and Networking Relationship. Thus undergraduates should seek opportunities to expose to different real-life circumstances in working environment. Field trips, internships, volunteer activities, and lectures with real-life examples are very helpful to provide undergraduates with such experiences. As long as they can detect their true competency levels, they can focus their best efforts to improve their employability.

Ex-students from IU are highly competent in various qualities by comparison with the employers' requirements. It shows that ex-students from IU generally do not disappoint their employers' expectation at the recruitment interview. However, ex-students fall shorts of employers' requirements on Change Leadership, Networking/Relationship Building, Organizational and Environmental Awareness. This again stresses the importance of being exposed to various working environments. In addition, outdoor and volunteer activities are very helpful to provide opportunities for undergraduates to experience network expansion. A change in IU curriculum should be considered to better prepare undergraduates for job market.

The research also shows that there is a great demand for ex-students to make improvements on the listed competencies. The mean of difference of 1.02 shows that in general, ex-students want to improve to new levels in these competencies. Ex-students have been aware that these competencies are critical for their professional advancement and personal development. Living in a dynamic business environment like Vietnam's, lifetime learning is a must for everyone, and ex-students are no exception. The International University should pay attention to this, and offer various short-courses that focus on improvement of these competencies. Beside the additional source of income, this activity can establish and strengthen its links with industries.

Furthermore, male and female undergraduates rate themselves equal in the majority of competencies except change leadership, networking/relationship building, results orientation, and team leadership. Therefore, to improve 
employability for female students, courses on these activities should be tailored and offered to female students with the subsidy of IU.

Finally, IU offers good assistance to undergraduates on improvement of these competencies during study period. Hence, IU has performed the training functions quite well since its establishment in December, 2003. However, after joining WTO in 2007, Vietnam promised to open its education sector in 2010. For the time being, many foreign universities, educational institutions are applying to set up their affiliates in Vietnam. With the core competency of using English as the only means of teaching, IU will face stiff competition in a very near future. This kind of research is very crucial for IU to make further improvements. It helps IU to sustain its development through producing competent undergraduates for ever-increasing demanding job market.

\section{References}

Boden, R., \& Maria, N. (2010). Employing discourse: Universities and graduate 'employability'. Journal of Education Policy, 25(1), 37-54. http://dx.doi.org/10.1080/02680930903349489

Bridgstock, R. (2009). The graduate attributes we've overlooked: Enhancing graduate employability through career management skills. Higher Education Research \& Development, 28(1), 31-44. http://dx.doi.org/doi:10.1080/07294360802444347

Brown, P., Green, A., Lauder, H., \& Sakamoto, A. (2001). High skill economies. London: Macmilan.

DEST. (2002a). Employability skills for the future. A report by the Australian Chamber of Commerce and Industry and the Business Council of Australia for the Department of Education, Science and Training, Canberra.

De Leon, J. E., \& Borchers, R. E. (1998). High School Graduate Employment Trends and the Skills Graduates Need to Enter Texas Manufacturing Industries. Journal of Vocational and Technical Education, 15(1), 28-41

Harvey, L. (2001). Defining and measuring employability. Quality in Higher Education, 7(2), 97-109, http://dx.doi.org/10.1080/13538320120059990

Holmes, L. (2001). Reconsidering graduate employability: the graduate identity approach, Quality in Higher Education, 7, 111-119. http://dx.doi.org/10.1080/13538320120060006

Harvey, L., Moon, S., Geall, V., \& Bower, R. (1997). Graduates' Work. Birmingham, Centre for Research into Quality.

Khir, K. (2006). Training employable graduates: Innovation in training methodology. In: National Conference on Continuing Technical Education \& Training 2006, Challenges in Technical Education and Training, Enhancing Employability among Graduates, 28-29 July 2006. The Katerina Hotel, Batu Pahat Johor.

Knight, P., \& Yorke, M. (2003). Employability and good learning in higher education. Teaching in Higher Education, 8(1), 3-16. http:/dx.doi.org/10.1080/1356251032000052294

Knight, P., \& Yorke, M. (2002). Skills plus: Tuning the Undergraduate Curriculum, Skills Plus Project Report, the Open University, United Kingdom.

Kamarainen, P., Attwell, G., \& Brown, A. (2002). Qualifications, competencies and learning environments for the future European reference publication, CEDEFOP, Thessaloniki.

Kamarainen, P., \& Streumer, J. (1998). Curriculum development, new learning environments, and transfer of innovations in Europe. In CEDEFOP Vocational Education and Training - the European Research Field, Background Report 1998, Vol. I, CEDEFOP, Thessaloniki.

Lees, D. (2002). Graduate employability - literature review. LTSN Generic Centre Website. [Online] Available: http://www.gla.ac.uk/employability/documents/litrev.rtf (August 8, 2008)

Mitchell, M. L. (2001). Importance of workplace skills needs for entry-level employment as perceived by secondary vocational students and employers., Ph. D. Graduate School of Wayne State University, Detroit, Michigan.

Nabi, G. R. (2003). Graduate employment and underemployment: Opportunity for skill use and career experiences amongst recent business graduates, Education and Training, 45(7), 371-382. http://dx.doi.org/10.1108/00400910310499947

Organizational Readiness Office. (2007). Behavioural Competency Dictionary. [Online] Available: http://www.tbs-sct.gc.ca/or-gc/itg-gti/behav-comp/behav-comp-eng.pdf (May 10, 2010)

Purcell, K., \& Pitcher, I. (1996). Great Expectation: the new diversity of graduate skills and aspirations. Coventry, Institute for Employment Research, University of Warwick. 
Singh, G. K. G., \& Singh, S. K. G. (2008). Malaysian Graduates’ Employability Skills. UNITAR E-JOURNAL, 4(1), $15-45$

Saravanan, V. (2006). Sustainable employability skills for engineering professionals. The Indian Review of World Literature in English, 5(2), 1-9

Sherer, M., \& Eadie, R. (1987). Employability skills: Key to success. Thrust, 17(2), 16-17

Tomlinson, M. (2008). 'The degree is not enough': Students' perceptions of the role of higher education credentials for graduate work and employability. British Journal of Sociology of Education, 29(1), 49-61. http://dx.doi.org/10.1080/01425690701737457

Wikimedia.

(2011).

[Online]

http://vi.wikipedia.org/wiki/Vi\%E1\%BB\%87t_Nam\#Gi.C3.A1o_d.E1.BB.A5c (June 12, 2011)

Available:

Wye, C. K., \& Lim, Y. M. (2009). Perception differential between employers and undergraduates on the importance of employability skills. International Education Studies, 2(1), 95-105

Table 1. Summary of levels of competencies required by employers/managers, possessed by ex-students and undergraduates, expected by ex-students to outperform the jobs, and the assistance levels that IU has helped undergraduates in the competency improvement.

\begin{tabular}{|c|c|c|c|c|c|c|}
\hline \multirow[b]{2}{*}{ Competencies } & \multicolumn{2}{|c|}{ Employers } & \multicolumn{2}{|c|}{ Ex_Students } & \multicolumn{2}{|c|}{ Undergraduates } \\
\hline & Mean & Stdev & Mean & Stdev & Mean & Stdev \\
\hline AdaptivN & \multirow[b]{2}{*}{2.69} & \multirow[b]{2}{*}{0.96} & \multirow{2}{*}{$\begin{array}{l}3.07 \\
4.02\end{array}$} & \multirow{2}{*}{$\begin{array}{l}0.95 \\
0.93\end{array}$} & 2.83 & 0.85 \\
\hline AdaptivR & & & & & & \multirow[b]{2}{*}{0.97} \\
\hline AdaptivH & & & & & 3.14 & \\
\hline \multirow{3}{*}{$\begin{array}{l}\text { CrithiN } \\
\text { CrithiR } \\
\text { CrithiH }\end{array}$} & \multirow[b]{2}{*}{2.38} & \multirow[b]{2}{*}{1.21} & \multirow{2}{*}{$\begin{array}{l}2.68 \\
3.86\end{array}$} & \multirow{2}{*}{$\begin{array}{l}1.05 \\
1.15\end{array}$} & 2.67 & 0.86 \\
\hline & & & & & \multirow[b]{2}{*}{2.87} & \multirow[b]{2}{*}{1.06} \\
\hline & & & & & & \\
\hline \multirow{3}{*}{$\begin{array}{l}\text { LeaderN } \\
\text { LeaderR } \\
\text { LeaderH }\end{array}$} & \multirow[b]{2}{*}{2.99} & \multirow[b]{2}{*}{1.05} & \multirow{2}{*}{$\begin{array}{l}2.39 \\
3.48\end{array}$} & \multirow{2}{*}{$\begin{array}{l}0.87 \\
0.85\end{array}$} & 3 & 0.99 \\
\hline & & & & & & \multirow[b]{2}{*}{1.00} \\
\hline & & & & & 3.07 & \\
\hline \multirow{3}{*}{$\begin{array}{l}\text { ClientN } \\
\text { ClientR } \\
\text { ClientH }\end{array}$} & \multirow{2}{*}{2.83} & \multirow{2}{*}{1.08} & \multirow{2}{*}{$\begin{array}{l}2.68 \\
4.07\end{array}$} & \multirow{2}{*}{$\begin{array}{l}0.91 \\
1.11\end{array}$} & 2.74 & 0.93 \\
\hline & & & & & & \multirow{2}{*}{1.03} \\
\hline & & & & & 2.99 & \\
\hline \multirow{3}{*}{$\begin{array}{l}\text { CommuniN } \\
\text { CommuniR } \\
\text { CommuniH }\end{array}$} & \multirow[b]{2}{*}{2.55} & \multirow[b]{2}{*}{0.93} & \multirow{2}{*}{$\begin{array}{l}3.14 \\
3.86\end{array}$} & \multirow{2}{*}{$\begin{array}{c}0.9 \\
1.09\end{array}$} & 2.94 & 1.01 \\
\hline & & & & & & \multirow[b]{2}{*}{0.94} \\
\hline & & & & & 3.31 & \\
\hline \multirow{3}{*}{$\begin{array}{l}\text { ConfliN } \\
\text { ConfliR } \\
\text { ConfliH }\end{array}$} & & & 2.41 & 0.87 & 2.79 & 0.96 \\
\hline & 2.76 & 1.18 & 3.32 & 1.05 & & \\
\hline & & & & & 3.03 & 1.17 \\
\hline LearnN & & & 3.16 & 0.91 & 2.94 & 0.98 \\
\hline LearnR & 3.34 & 1.11 & 3.93 & 0.97 & & \\
\hline
\end{tabular}




\begin{tabular}{|c|c|c|c|c|c|c|}
\hline LearnH & & & & & 3.17 & 0.95 \\
\hline \multirow{3}{*}{$\begin{array}{l}\text { CreateN } \\
\text { CreateR } \\
\text { CreateH }\end{array}$} & \multirow[b]{2}{*}{2.85} & \multirow[b]{2}{*}{1.19} & \multirow{2}{*}{$\begin{array}{l}2.66 \\
3.57\end{array}$} & \multirow{2}{*}{$\begin{array}{l}1.16 \\
1.19\end{array}$} & 2.67 & 1.15 \\
\hline & & & & & \multirow[b]{2}{*}{2.94} & \multirow[b]{2}{*}{1.11} \\
\hline & & & & & & \\
\hline \multirow{3}{*}{$\begin{array}{l}\text { DeciN } \\
\text { DeciR } \\
\text { DeciH }\end{array}$} & \multirow[b]{2}{*}{3.06} & \multirow[b]{2}{*}{0.96} & \multirow{2}{*}{$\begin{array}{c}2.86 \\
3.7\end{array}$} & \multirow{2}{*}{$\begin{array}{l}1.13 \\
1.00\end{array}$} & 3.03 & 0.90 \\
\hline & & & & & \multirow[b]{2}{*}{3.01} & \multirow[b]{2}{*}{1.08} \\
\hline & & & & & & \\
\hline \multirow{3}{*}{$\begin{array}{l}\text { InitiaN } \\
\text { InitiaR } \\
\text { InitiaH }\end{array}$} & \multirow[b]{2}{*}{2.73} & \multirow[b]{2}{*}{1.29} & \multirow{2}{*}{$\begin{array}{l}2.84 \\
3.98\end{array}$} & \multirow{2}{*}{$\begin{array}{l}1.48 \\
1.19\end{array}$} & 2.97 & 1.20 \\
\hline & & & & & \multirow[b]{2}{*}{3.17} & \multirow[b]{2}{*}{0.99} \\
\hline & & & & & & \\
\hline \multirow{3}{*}{$\begin{array}{l}\text { NetworkN } \\
\text { NetworkR } \\
\text { NetworkH }\end{array}$} & \multirow[b]{2}{*}{3.05} & \multirow[b]{2}{*}{1.01} & \multirow{2}{*}{$\begin{array}{l}2.52 \\
4.00\end{array}$} & \multirow{2}{*}{$\begin{array}{l}0.82 \\
1.06\end{array}$} & 2.91 & 1.06 \\
\hline & & & & & & \multirow[b]{2}{*}{1.25} \\
\hline & & & & & 2.97 & \\
\hline \multirow{3}{*}{$\begin{array}{l}\text { EnvironN } \\
\text { EnvironR } \\
\text { EnvironH }\end{array}$} & \multirow[b]{2}{*}{3.30} & & 2.55 & 1.09 & 2.81 & 1.03 \\
\hline & & 1.12 & 3.77 & 1.16 & & \\
\hline & & & & & 2.89 & 1.12 \\
\hline PartnerN & & & 2.55 & 1.00 & 2.77 & 1.00 \\
\hline PartnerR & 2.69 & 1.23 & 3.86 & 1.30 & & \\
\hline PartnerH & & & & & 2.93 & 1.16 \\
\hline PlanN & & & 2.23 & 1.12 & 2.4 & 1.15 \\
\hline PlanR & 2.55 & 1.28 & 3.34 & 1.33 & & \\
\hline PlanH & & & & & 2.87 & 1.09 \\
\hline ResultN & & & 2.07 & 1.11 & 2.41 & 1.12 \\
\hline ResulR & 2.08 & 0.98 & 3.36 & 1.28 & & \\
\hline ResultH & & & & & 2.76 & 1.03 \\
\hline RiskN & & & 2.57 & 0.82 & 2.67 & 0.91 \\
\hline RiskR & 2.61 & 1.06 & 3.16 & 1.26 & & \\
\hline RiskH & & & & & 2.93 & 0.98 \\
\hline ResourN & & & 2.32 & 1.01 & 2.61 & 1.12 \\
\hline ResourR & 2.18 & 0.99 & 3.5 & 1.23 & & \\
\hline ResourH & & & & & 2.81 & 1.07 \\
\hline StressN & & & 2.73 & 1.00 & 2.59 & 0.94 \\
\hline StressR & 2.59 & 1.00 & 3.88 & 1.00 & & \\
\hline
\end{tabular}




\begin{tabular}{|c|c|c|c|c|c|c|}
\hline StressH & & & & & 2.81 & 1.13 \\
\hline \multirow{3}{*}{$\begin{array}{l}\text { TeamWorN } \\
\text { TeamWorR } \\
\text { TeamWorH }\end{array}$} & & & 2.89 & 1.20 & 3.04 & 1.17 \\
\hline & 3.08 & 1.19 & 3.93 & 1.35 & \multirow[b]{2}{*}{3.53} & \multirow[b]{2}{*}{1.11} \\
\hline & & & & & & \\
\hline \multirow{3}{*}{$\begin{array}{l}\text { TeamleaN } \\
\text { TeamleaR } \\
\text { TeamleaH }\end{array}$} & & & 2.95 & 1.31 & 2.97 & 1.20 \\
\hline & 3.15 & 1.48 & 3.82 & 1.43 & \multirow[b]{2}{*}{3.43} & \multirow[b]{2}{*}{1.12} \\
\hline & & & & & & \\
\hline \multirow{3}{*}{$\begin{array}{l}\text { EthicN } \\
\text { EthicR } \\
\text { EthicH }\end{array}$} & & & 2.75 & 1.31 & 3.03 & 1.08 \\
\hline & 3.11 & 1.32 & 3.59 & 1.24 & \multirow[b]{2}{*}{3.1} & \multirow[b]{2}{*}{1.19} \\
\hline & & & & & & \\
\hline \multirow{3}{*}{$\begin{array}{l}\text { EnglishN } \\
\text { EnglishR } \\
\text { EnglishH }\end{array}$} & & & 2.52 & 0.59 & 1.86 & 0.84 \\
\hline & 1.78 & 0.84 & 2.93 & 0.97 & \multirow[b]{2}{*}{2.76} & \multirow[b]{2}{*}{1.11} \\
\hline & & & & & & \\
\hline
\end{tabular}


Table 2. The differences between the levels of competencies possessed by undergraduates and those required by employers/managers.

\begin{tabular}{|c|c|c|c|c|c|c|}
\hline \multirow[t]{2}{*}{ Competencies } & \multicolumn{2}{|c|}{ Undergraduates } & \multicolumn{2}{|c|}{ Employers } & \multirow{2}{*}{$\begin{array}{l}\text { Level of } \\
\text { mismatch }\end{array}$} & \multirow[b]{2}{*}{ Significant } \\
\hline & Mean & Stdev & Mean & Stdev & & \\
\hline Adaptability & 2.83 & 0.85 & 2.69 & 0.96 & -0.14 & \\
\hline Analytical Think & 2.67 & 0.86 & 2.38 & 1.21 & -0.29 & \\
\hline Change Leadership & 3 & 0.99 & 2.99 & 1.05 & -0.01 & \\
\hline Client Focus & 2.74 & 0.93 & 2.83 & 1.08 & 0.09 & \\
\hline Communication & 2.94 & 1.01 & 2.55 & 0.93 & -0.39 & $* *$ \\
\hline Conflict management & 2.79 & 0.96 & 2.76 & 1.18 & -0.03 & \\
\hline Continuous learning & 2.94 & 0.98 & 3.34 & 1.11 & 0.40 & $* *$ \\
\hline Creative Thinking & 2.67 & 0.15 & 2.85 & 1.19 & 0.18 & \\
\hline Decision making & 3.03 & 0.90 & 3.06 & 0.96 & 0.03 & \\
\hline Initiative & 2.97 & 1.20 & 2.73 & 1.29 & -0.24 & \\
\hline Networking/Relationship building & 2.91 & 1.06 & 3.05 & 1.01 & 0.14 & \\
\hline Organization \& Environment Awareness & 2.81 & 1.03 & 3.30 & 1.12 & 0.49 & $* *$ \\
\hline Partnering & 2.77 & 1.00 & 2.69 & 1.23 & -0.08 & \\
\hline Planning and Organizing & 2.4 & 1.15 & 2.55 & 1.28 & 0.15 & \\
\hline Results Orientation & 2.41 & 1.12 & 2.08 & 0.98 & -0.33 & \\
\hline Risk management & 2.67 & 0.91 & 2.61 & 1.06 & -0.06 & \\
\hline Use of Resources & 2.61 & 1.12 & 2.18 & 0.99 & -0.43 & $* *$ \\
\hline Stress management & 2.59 & 0.94 & 2.59 & 1.00 & 0.00 & \\
\hline Teamwork & 3.04 & 1.17 & 3.08 & 1.19 & 0.04 & \\
\hline Team leadership & 2.97 & 1.20 & 3.15 & 1.48 & 0.18 & \\
\hline Values and Ethics & 3.03 & 1.08 & 3.11 & 1.32 & 0.08 & \\
\hline English skills & 1.86 & 0.84 & 1.78 & 0.84 & -0.08 & \\
\hline
\end{tabular}

Note: ** Independent-Samples T test is statistically significant at 0.05 alpha level 
Table 3. The differences between the levels of competencies possessed by ex-students and undergraduates.

\begin{tabular}{|c|c|c|c|c|c|c|}
\hline \multirow[t]{2}{*}{ Competencies } & \multicolumn{2}{|c|}{ Undergraduates } & \multicolumn{2}{|c|}{$\begin{array}{l}\text { Ex-students } \\
\text { (now) }\end{array}$} & \multirow{2}{*}{$\begin{array}{c}\text { Level of } \\
\text { Improvement }\end{array}$} & \multirow[b]{2}{*}{ Significant } \\
\hline & Mean & Stdev & Mean & Stdev & & \\
\hline Adaptability & 2.83 & 0.85 & 3.07 & 0.95 & 0.24 & \\
\hline Analytical Think & 2.67 & 0.86 & 2.68 & 1.05 & 0.01 & \\
\hline Change Leadership & 3.00 & 0.99 & 2.39 & 0.87 & -0.61 & $* *$ \\
\hline Client Focus & 2.74 & 0.93 & 2.68 & 0.91 & -0.06 & \\
\hline Communication & 2.94 & 1.01 & 3.14 & 0.9 & 0.20 & \\
\hline Conflict management & 2.79 & 0.96 & 2.41 & 0.87 & -0.38 & $* *$ \\
\hline Continuous learning & 2.94 & 0.98 & 3.16 & 0.91 & 0.22 & \\
\hline Creative Thinking & 2.67 & 0.15 & 2.66 & 1.16 & -0.01 & \\
\hline Decision making & 3.03 & 0.90 & 2.86 & 1.13 & -0.17 & \\
\hline Initiative & 2.97 & 1.20 & 2.84 & 1.48 & -0.13 & \\
\hline Networking/Relationship building & 2.91 & 1.06 & 2.52 & 0.82 & -0.39 & $* *$ \\
\hline Organization \& Environment Awareness & 2.81 & 1.03 & 2.55 & 1.09 & -0.26 & \\
\hline Partnering & 2.77 & 1.00 & 2.55 & 1.00 & -0.22 & \\
\hline Planning and Organizing & 2.4 & 1.15 & 2.23 & 1.12 & -0.17 & \\
\hline Results Orientation & 2.41 & 1.12 & 2.07 & 1.11 & -0.34 & \\
\hline Risk management & 2.67 & 0.91 & 2.57 & 0.82 & -0.10 & \\
\hline Use of Resources & 2.61 & 1.12 & 2.32 & 1.01 & -0.29 & \\
\hline Stress management & 2.59 & 0.94 & 2.73 & 1.00 & 0.14 & \\
\hline Teamwork & 3.04 & 1.17 & 2.89 & 1.20 & -0.15 & \\
\hline Team leadership & 2.97 & 1.2 & 2.95 & 1.31 & -0.02 & \\
\hline Values and Ethics & 3.03 & 1.08 & 2.75 & 1.31 & -0.28 & \\
\hline English skills & 1.86 & 0.84 & 2.52 & 0.59 & 0.66 & $* *$ \\
\hline
\end{tabular}

Notes: 0 being No Mismatch; 4 being Highest Level of Mismatch

** Independent-Samples $\mathrm{T}$ test is statistically significant at 0.05 alpha level 
Table 4. The differences between the levels of competencies possessed by ex-students and those required by employers/managers

\begin{tabular}{|c|c|c|c|c|c|c|}
\hline \multirow[t]{2}{*}{ Competencies } & \multicolumn{2}{|c|}{$\begin{array}{l}\text { Ex-students } \\
\text { (now) }\end{array}$} & \multicolumn{2}{|c|}{ Employers } & \multirow{2}{*}{$\begin{array}{l}\text { Level of } \\
\text { mismatch }\end{array}$} & \multirow[b]{2}{*}{ Significant } \\
\hline & Mean & Stdev & Mean & Stdev & & \\
\hline Adaptability & 3.07 & 0.95 & 2.69 & 0.96 & -0.38 & \\
\hline Analytical Think & 2.68 & 1.05 & 2.38 & 1.21 & -0.30 & \\
\hline Change Leadership & 2.39 & 0.87 & 2.99 & 1.05 & 0.60 & $* *$ \\
\hline Client Focus & 2.68 & 0.91 & 2.83 & 1.08 & 0.15 & \\
\hline Communication & 3.14 & 0.90 & 2.55 & 0.93 & -0.59 & $* *$ \\
\hline Conflict management & 2.41 & 0.87 & 2.76 & 1.18 & 0.35 & \\
\hline Continuous learning & 3.16 & 0.91 & 3.34 & 1.11 & 0.18 & \\
\hline Creative Thinking & 2.66 & 1.16 & 2.85 & 1.19 & 0.19 & \\
\hline Decision making & 2.86 & 1.13 & 3.06 & 0.96 & 0.20 & \\
\hline Initiative & 2.84 & 1.48 & 2.73 & 1.29 & -0.11 & \\
\hline Networking/Relationship building & 2.52 & 0.82 & 3.05 & 1.01 & 0.53 & $* *$ \\
\hline Organization \& Environment Awareness & 2.55 & 1.09 & 3.30 & 1.12 & 0.75 & $* *$ \\
\hline Partnering & 2.55 & 1.00 & 2.69 & 1.23 & 0.14 & \\
\hline Planning and Organizing & 2.23 & 1.12 & 2.55 & 1.28 & 0.32 & \\
\hline Results Orientation & 2.07 & 1.11 & 2.08 & 0.98 & 0.01 & \\
\hline Risk management & 2.57 & 0.82 & 2.61 & 1.06 & 0.04 & \\
\hline Use of Resources & 2.32 & 1.01 & 2.18 & 0.99 & -0.14 & \\
\hline Stress management & 2.73 & 1.00 & 2.59 & 1.00 & -0.14 & \\
\hline Teamwork & 2.89 & 1.20 & 3.08 & 1.19 & 0.19 & \\
\hline Team leadership & 2.95 & 1.31 & 3.15 & 1.48 & 0.20 & \\
\hline Values and Ethics & 2.75 & 1.31 & 3.11 & 1.32 & 0.36 & \\
\hline English skills & 2.52 & 0.59 & 1.78 & 0.84 & -0.74 & $* *$ \\
\hline
\end{tabular}

Notes: 0 being No Mismatch; 4 being Highest Level of Mismatch

** Independent-Samples $\mathrm{T}$ test is statistically significant at 0.05 alpha level 
Table 5. The differences between levels of competencies which is expected to outperform the job and competencies possessed by ex-students

\begin{tabular}{|l|c|c|l|}
\hline Competencies & Mean of Difference & Stdev & Significant \\
\hline Adaptability & 0.95 & 1.16 & $* *$ \\
\hline Analytical Think & 1.18 & 0.87 & $* *$ \\
\hline Change Leadership & 1.09 & 1.07 & $* *$ \\
\hline Client Focus & 1.39 & 1.10 & $* *$ \\
\hline Communication & 0.73 & 1.00 & $* *$ \\
\hline Conflict management & 0.91 & 1.16 & $* *$ \\
\hline Continuous learning & 0.77 & 1.16 & $* *$ \\
\hline Creative Thinking & 0.91 & 1.31 & $* *$ \\
\hline Decision making & 0.84 & 1.10 & $* *$ \\
\hline Initiative & 1.14 & 1.55 & $* *$ \\
\hline Networking/Relationship building & 1.48 & 1.15 & $* *$ \\
\hline Organization \& Environment Awareness & 1.23 & 1.26 & $* *$ \\
\hline Partnering & 1.32 & 1.22 & $* *$ \\
\hline Planning and Organizing & 1.11 & 1.28 & $* *$ \\
\hline Results Orientation & 1.30 & 1.27 & $* *$ \\
\hline Risk management & 0.59 & 1.23 & $* *$ \\
\hline Use of Resources & 1.18 & 1.21 & $* *$ \\
\hline Stress management & 1.07 & 0.95 & $* *$ \\
\hline Teamwork & 0.86 & 1.35 & $* *$ \\
\hline Team leadership & 0.84 & 1.30 & $* *$ \\
\hline Values and Ethics & 0.41 & 1.20 & $* *$ \\
\hline English skills & & 0.95 & $* *$ \\
\hline & & $* 5$ \\
\hline
\end{tabular}

Mean $=1.02$

Stdev $=0.26$

Note: ** Paired-samples T-test is significant at 0.05 alpha level. 
Table 6. The sex differences in levels of competencies self-rated by undergraduates

\begin{tabular}{|c|c|c|c|c|c|c|c|}
\hline Competencies & Sex & Number & Mean & Stdev & Std. Error Mean & Difference & Significant \\
\hline \multirow[t]{2}{*}{ AdaptivN } & Male & 24 & 2.96 & 0.86 & 0.18 & \multirow[t]{2}{*}{0.20} & \\
\hline & Female & 46 & 2.76 & 0.85 & 0.13 & & \\
\hline \multirow[t]{2}{*}{ CriThiN } & Male & 24 & 2.75 & 0.90 & 0.18 & \multirow[t]{2}{*}{0.12} & \\
\hline & Female & 46 & 2.63 & 0.85 & 0.13 & & \\
\hline \multirow[t]{2}{*}{ LeaderN } & Male & 24 & 3.38 & 0.97 & 0.20 & \multirow[t]{2}{*}{0.57} & \multirow[t]{2}{*}{$* *$} \\
\hline & Female & 46 & 2.80 & 0.96 & 0.14 & & \\
\hline \multirow[t]{2}{*}{ ClientN } & Male & 24 & 2.75 & 0.90 & 0.18 & \multirow[t]{2}{*}{0.01} & \\
\hline & Female & 46 & 2.74 & 0.95 & 0.14 & & \\
\hline \multirow[t]{2}{*}{ CommuniN } & Male & 24 & 3.17 & 1.13 & 0.23 & \multirow[t]{2}{*}{0.34} & \\
\hline & Female & 46 & 2.83 & 0.93 & 0.14 & & \\
\hline \multirow[t]{2}{*}{ ConfliN } & Male & 24 & 2.92 & 1.14 & 0.23 & \multirow[t]{2}{*}{0.20} & \\
\hline & Female & 46 & 2.72 & 0.86 & 0.13 & & \\
\hline \multirow[t]{2}{*}{ LearnN } & Male & 24 & 3.00 & 1.06 & 0.22 & \multirow[t]{2}{*}{0.09} & \\
\hline & Female & 46 & 2.91 & 0.94 & 0.14 & & \\
\hline \multirow[t]{2}{*}{ CreateN } & Male & 24 & 2.75 & 1.36 & 0.28 & \multirow[t]{2}{*}{0.12} & \\
\hline & Female & 46 & 2.63 & 1.04 & 0.15 & & \\
\hline \multirow[t]{2}{*}{ DeciN } & Male & 24 & 3.25 & 1.07 & 0.22 & \multirow[t]{2}{*}{0.34} & \\
\hline & Female & 46 & 2.91 & 0.78 & 0.12 & & \\
\hline \multirow[t]{2}{*}{ InitiaN } & Male & 24 & 3.17 & 1.37 & 0.28 & \multirow[t]{2}{*}{0.30} & \\
\hline & Female & 45 & 2.87 & 1.12 & 0.17 & & \\
\hline \multirow[t]{2}{*}{ NetworkN } & Male & 24 & 3.38 & 1.13 & 0.23 & \multirow[t]{2}{*}{0.70} & \multirow[t]{2}{*}{$* *$} \\
\hline & Female & 46 & 2.67 & 0.94 & 0.14 & & \\
\hline PartnerN & Male & 24 & 2.83 & 1.01 & 0.21 & 0.10 & \\
\hline & Female & 45 & 2.73 & 1.01 & 0.15 & & \\
\hline PlanN & Male & 24 & 2.38 & 1.24 & 0.25 & -0.04 & \\
\hline & Female & 46 & 2.41 & 1.11 & 0.16 & & \\
\hline ResultN & Male & 24 & 2.79 & 1.14 & 0.23 & 0.57 & $* *$ \\
\hline & Female & 46 & 2.22 & 1.07 & 0.16 & & \\
\hline RiskN & Male & 24 & 2.54 & 0.98 & 0.20 & -0.20 & \\
\hline & Female & 46 & 2.74 & 0.88 & 0.13 & & \\
\hline ResourN & Male & 22 & 2.55 & 1.18 & 0.25 & -0.13 & \\
\hline & Female & 46 & 2.67 & 1.12 & 0.16 & & \\
\hline StressN & Male & 24 & 2.79 & 1.10 & 0.23 & 0.31 & \\
\hline & Female & 46 & 2.48 & 0.84 & 0.12 & & \\
\hline TeamWorN & Male & 24 & 3.21 & 1.22 & 0.25 & 0.25 & \\
\hline & Female & 46 & 2.96 & 1.15 & 0.17 & & \\
\hline TeamleaN & Male & 24 & 3.42 & 1.21 & 0.25 & 0.68 & $* *$ \\
\hline & Female & 46 & 2.74 & 1.14 & 0.17 & & \\
\hline EthicN & Male & 24 & 3.38 & 1.28 & 0.26 & 0.51 & \\
\hline & Female & 45 & 2.87 & 0.92 & 0.14 & & \\
\hline EnglishN & Male & 24 & 2.00 & 0.88 & 0.18 & 0.22 & \\
\hline & Female & 46 & 1.78 & 0.81 & 0.12 & & \\
\hline
\end{tabular}

Note: ** Independent-Samples T test is statistically significant at 0.05 alpha level 
Table 7. The assistance levels that IU undergraduates have received during study period to improve competencies

\begin{tabular}{|l|c|c|}
\hline \multirow{2}{*}{ Competencies } & \multicolumn{2}{|c|}{ Undergraduates } \\
\cline { 2 - 3 } AdaptivH & Mean & Stdev \\
\hline CrithiH & 3.14 & 0.97 \\
\hline LeaderH & 2.87 & 1.06 \\
\hline ClientH & 3.07 & 1.00 \\
\hline CommuniH & 2.99 & 1.03 \\
\hline ConfliH & 3.31 & 0.94 \\
\hline LearnH & 3.03 & 1.17 \\
\hline CreateH & 3.17 & 0.95 \\
\hline DeciH & 3.01 & 1.11 \\
\hline InitiaH & 3.17 & 1.08 \\
\hline NetworkH & 2.97 & 1.25 \\
\hline EnvironH & 2.89 & 1.12 \\
\hline PartnerH & 2.93 & 1.16 \\
\hline PlanH & 2.87 & 1.09 \\
\hline ResultH & 2.76 & 1.03 \\
\hline RiskH & 2.93 & 0.98 \\
\hline ResourH & 2.81 & 1.07 \\
\hline StressH & 2.81 & 1.13 \\
\hline TeamWorH & 3.53 & 1.11 \\
\hline TeamleaH & 3.43 & 1.12 \\
\hline EthicH & 3.1 & 1.19 \\
\hline EnglishH & 2.76 & 1.11 \\
\hline
\end{tabular}

Mean $=3.02$

Stdev $=0.21$ 